ISSN 0258-7122

Bangladesh J. Agril. Res. 36(3) : 469-476, September 2011

\title{
CAUSES OF YIELD GAPS AND STRATEGIES FOR MINIMIZING THE GAPS IN DIFFERENT CROPS OF BANGLADESH
}

\author{
MOHAMMAD H. MONDAL ${ }^{1}$
}

\begin{abstract}
The concept of yield gaps originated from the studies conducted by IRRI in the seventies. The yield gap discussed in this paper is the difference between the potential farm yield and the actual average farm yield. In Bangladesh, yield gaps exist in different crops ranging up to $60 \%$. According to the recent study conducted by BRRI, the yield gap in rice was estimated at $1.74 \mathrm{t} / \mathrm{ha}$. The existence of yield gaps was as well observed in rice, mustard, wheat and cotton in India. In India, yield gap varied from 15.5 to $60 \%$ with the national average gap of $52.3 \%$ in irrigated ecosystem. The yield gaps are mainly caused by biological, socio-economic, climate and institutional/policy related factors. Different strategies, such as integrated crop management (1CM) practices, timely supply of inputs including credit to farmers, research and extension collaboration to transfer the new technologies have been discussed as strategies to minimize yield gaps. Suggestions have been made to make credit available to resource-poor small farmers to buy necessary inputs. Reducing transaction cost, simplifying lending procedures and strengthening monitoring mechanism of the current credit system are, however, essential to enable the farmers to avail the credit facility. Efforts should be made to update farmers' knowledge on the causes of yield gaps in crops and measures to narrow the gaps through training, demonstrations, field visits and monitoring by extension agencies to achieve high yield. The government should realize that yield gaps exist in different crops of Bangladesh and therefore, explore the scope to increase production as well as productivity of crops by narrowing the yield gap and thereby ensure food security.
\end{abstract}

Keywords: Yield gaps, strategies, crops of Bangladesh.

\section{Introduction}

The concept of yield gaps in crops originated from different constraint studies carried out by International Rice Research Institute (IRRI) during the seventies. The yield gap comprises at least two components. The first component-yield gap I is the difference between experiment/research station yield and the potential farm yield. This component is not exploitable. The second component of yield gap II is the difference between the potential farm yield and the actual average farm yield (Alam, 2006). The yield gap II is exploitable and can be minimized by deploying research and extension approaches and government interventions, especially institutional issues. The yield gap II in this paper has been discussed as the 'yield gap'.

${ }^{1}$ Director General (Retd.), Bangladesh Agricultural Research Institute (BARI), Joydebpur, Gazipur, Bangladesh. 
In Bangladesh, despite the technologies developed by different National Agricultural Research System (NARS) institutes and extension agencies to disseminate the technologies, yield gaps exist in different crops of Bangladesh, such as rice, wheat, potato, oilseeds, pulses, etc. that may range from $19 \%$ to about 64\% of the potential yield (Alam, 2006; OFRD, 2003-2004 \& 2008-2009; Roy, 1997; Matin et al., 1996). The existence of yield gaps was also observed in rice, mustard, and cotton in India (Aggarwal, 2008). In India, yield gap varied from 15.5 to $60 \%$ with the national average gap of $52.3 \%$ in the irrigated ecosystem (Siddiq, 2000).

Yield gaps in crops are real and the challenge needs to be addressed in the interest of increased and sustainable crop production. The objective of this review article is to discuss the causes contributing to yield gaps in crops, suggest strategies to minimize the gaps to increase yield and finally make recommendations mainly to the government/policy makers to develop guidelines or action plans to address the problem.

\section{Crop yield gaps in Bangladesh}

Yield gaps exist in different crops of Bangladesh. To evaluate the yield gap in boro rice, a study was conducted by BRRI in Rajapur village of Bhanga upazila of Faridpur and Meghdubi village of Gazipur districts (Alam, 2006). Under farmer's practice, the yields of boro rice were $4.47 \mathrm{t} / \mathrm{ha}$ and $3.67 \mathrm{t} / \mathrm{ha}$, while the potential yields with better management were $5.90 \mathrm{t} / \mathrm{ha}$ and $4.73 \mathrm{t} / \mathrm{ha}$ at Rajapur and Meghdubi villages, respectively. The yield gaps were thus $1.43 \mathrm{t} / \mathrm{ha}$ and 1.06 t/ha which were $24.24 \%$ and $22.41 \%$ of the potential yield at Rajapur and Meghdubi, respectively (Table 1). Roy (1997) reported yield gaps of 44.44 and $60.00 \%$ in aus and aman, respectively (Table2).

Table 1. Yield and yield gap in boro rice.

\begin{tabular}{|c|c|c|}
\hline \multirow{2}{*}{ Yield level/Yield gap } & \multicolumn{2}{|c|}{ Yield (t/ha)/village } \\
\hline & Rajapur & Meghdubi \\
\hline Potential yield & 5.90 & 4.73 \\
\hline Farmers' average yield & 4.47 & 3.67 \\
\hline Yield gap & 1.43 & 1.06 \\
\hline Yield gap (\%) & 24.24 & 22.41 \\
\hline
\end{tabular}

Table 2.Yield level and yield gap in rice-Farmers' and demo average.

\begin{tabular}{l|l|l|l|l}
\hline \multirow{2}{*}{ Rice } & \multicolumn{3}{|c|}{ Yield (t/ha) } & \multirow{2}{*}{ Yield gap (\%) } \\
\cline { 2 - 4 } & $\begin{array}{c}\text { National/farmers' } \\
\text { average }\end{array}$ & Demo average & Yield gap & \\
\hline MV aman & 2.20 & 5.50 & 3.30 & 60.00 \\
MV aus & 2.00 & 3.60 & 1.60 & 44.44 \\
\hline
\end{tabular}


Table 3 depicts yield levels and yield gaps in other economic crops of the country, such as wheat, potato, sweet potato, mustard, groundnut, sesame, lentil, chickpea, tomato, radish, and jute. An yield gap study was carried out by OFRD on wheat (var. Kanchan) at the MLT site Palashbari, Rangpur (OFRD, 20032004). It was observed that the better managed plot gave higher yield of $2.56 \mathrm{t} / \mathrm{ha}$ whereas the average managed farmers' plot yield was $1.87 \mathrm{t} / \mathrm{ha}$ indicating a yield gap of $27 \%$. A similar study was undertaken at the MLT site, Atgharia upazila of Pabna district to evaluate the yield gap in mustard using the variety BARI Sharisha-13 (OFRD, 2008-2009). Better managed plots gave higher yield (1366 $\mathrm{kg} / \mathrm{ha}$ ) than farmers' practice (894 $\mathrm{kg} / \mathrm{ha}$ ) with an yield gap of $35.03 \%$. Yield gaps of groundnut and sesame were found to be $26.66 \%$ and $33.33 \%$, respectively (ORC, BARI, 2002). In Potato and sweet potato, yield gaps were 44.72 and $64.01 \%$, respectively, between demo and farmers' average. Yield gap study was also conducted by OFRD with chickpea (var. BARI Chola-5).The study revealed yield gap of 31.43\% in chickpea (OFRD 2003-2004). Likewise, yield gaps of $32.35 \%$ and $19 \%$ were found in potato, sweet potato, lentil, and jute, respectively (Roy, 1997). A study was also undertaken to assess yield gap in tomato (var. Ratan) and radish (var. Tasaki sun). The yield gaps were found to be $36.68 \%$ and $40.28 \%$, respectively (Matin et al., 1996; Roy, 1997). It is thus evident from Table 3 that yield gaps in different crops varied from 19\% to 64\%.

Table 3. Yield levels and yield gaps in different crops.

\begin{tabular}{|c|c|c|c|c|}
\hline \multirow[b]{2}{*}{ Crops } & \multicolumn{3}{|c|}{ Yield (t/ha) } & \multirow[b]{2}{*}{ Yield gap (\%) } \\
\hline & $\begin{array}{c}\text { National/farmers' } \\
\text { average }\end{array}$ & \begin{tabular}{|c|} 
Better \\
managed/demo \\
average \\
\end{tabular} & Yield gap & \\
\hline Wheat & 1.87 & 2.56 & 0.69 & 26.95 \\
\hline Jute & 1.62 & 2.00 & 0.38 & 19.00 \\
\hline \multicolumn{5}{|l|}{ Oilseeds } \\
\hline Mustard & 0.89 & 1.37 & 0.48 & 35.03 \\
\hline Groundnut & 1.10 & 1.50 & 0.40 & 26.66 \\
\hline Sesame & 0.60 & 0.90 & 0.30 & 33.33 \\
\hline \multicolumn{5}{|l|}{ Tuber/roots } \\
\hline Potato & 10.69 & 19.37 & 8.65 & 44.72 \\
\hline Sweet potato & 9.58 & 26.62 & 17.04 & 64.01 \\
\hline \multicolumn{5}{|l|}{ Pulses } \\
\hline Lentil & 0.79 & 1.02 & 0.33 & 32.35 \\
\hline Chickpea & 0.72 & 1.05 & 0.33 & 31.43 \\
\hline \multicolumn{5}{|l|}{ Vegetables } \\
\hline Tomato & 32.61 & 51.50 & 18.89 & 36.68 \\
\hline Radish & 8.63 & 14.45 & 5.80 & 40.28 \\
\hline
\end{tabular}


A workshop was held recently on "minimizing rice yield gap" at BRRI, Gazipur where different experts observed that the issue of rice yield gap was worthy of receiving national priority, particularly in the context of food security. According to a study conducted by BRRI, the yield gap in rice was about 1.74 $\mathrm{t} / \mathrm{ha}$ and at least Tk. 1260 billion could be earned from the additional production annually by narrowing the yield gap (BRRI, 2011).

\section{Crop yield gaps in other countries}

Yield gaps in crops were also observed in other countries, especially those of Asia region. Table 4 illustrates the rice yield gaps in India, Nepal, Thailand, etc. While it was only 3.38\% in China, yield gap in other countries varied from 17 to $50 \%$ (Tran, 2000). Yield gaps in wheat (100-800 kg/ha), mustard (500-640 $\mathrm{kg} / \mathrm{ha}$ ), and cotton (790-1220 kg/ha) were also observed in different states of India, (Aggarwal, 2008).

Table 4. Yield levels and yield gaps in rice of several countries of Asia region.

\begin{tabular}{l|l|l|c|c}
\hline \multicolumn{1}{c|}{ Country } & $\begin{array}{c}\text { National average } \\
\text { yield (t/ha) }\end{array}$ & $\begin{array}{c}\text { Irrigated/better } \\
\text { managed yield (t/ha) }\end{array}$ & $\begin{array}{c}\text { Yield gap } \\
(\mathrm{t} / \mathrm{ha})\end{array}$ & $\begin{array}{c}\text { Yield gap } \\
(\%)\end{array}$ \\
\hline India & 2.60 & 3.60 & 1.00 & 27.78 \\
Nepal & 2.50 & 4.20 & 1.70 & 40.47 \\
Thailand & 2.00 & 4.00 & 2.00 & 50.00 \\
Vietnam & 3.10 & 4.30 & 1.20 & 27.90 \\
Indonesia & 4.40 & 5.30 & 0.90 & 17.00 \\
Philippines & 2.80 & 3.40 & 0.60 & 17.65 \\
China & 5.70 & 5.90 & 0.20 & 3.38 \\
\hline
\end{tabular}

In spite of this reality, some crop specialists, especially extension experts do not believe in the existence of yield gaps in the crops of Bangladesh. They tend to believe that the current strategy of the use of modern varieties and hybrid technology is sufficient to promote production and productivity of crops.

\section{Factors Causing Yield Gaps in Crops}

Several factors can cause yield gaps in crops. In general, factors causing yield gaps can be classified as follows (RAP, 1999):

\section{Biological factors}

Variety, soil fertility, management practices (fertilizer, water, pests management, etc.)

\section{Socio-economic factors}

Social and economic status of farmers, family size, farm holding, knowledge and education level of farmers, contact with extension agents. 


\section{Climatic factors}

Flood, drought, salinity, etc. caused by climatic changes.

\section{Institutional/government policy related factors}

Input/ output price, availability of inputs, credit supply, tenancy, etc. The price of produces and fertilizers could influence the rate of fertilizer use by farmers and thereby yield.

\section{Factors promoting technology transfer}

Research-extension linkage, training of extension personnel on the new technology, their knowledge and education level about the technology, demonstration of the technology, field visits and monitoring, etc. by extension.

\section{Strategies for Minimizing Yield Gaps}

\section{Promotion of integrated crop management}

Yield gaps caused by biological, socio-economic, and institutional constraints can be effectively addressed through an integrated crop management (1CM) practices. Transfer of the practices through extension agents could effectively help farmers minimize yield gaps. Timely planting, irrigation, weeding, plant protection, and timely harvesting could account for more than $20 \%$ yield increase (Siddiq, 2000). However, input/output prices and employment opportunities influence farmers' decision on the level of inputs to be applied.

\section{Adequate input and credit supplies}

Inputs play an important role in the productivity of crops and minimizing yield gaps. Farmers need adequate amounts of quality inputs at the right time to obtain high yields. It is also important that the fertilizer inputs are integrated with organic manures for balanced use of nutrients. Resource-poor small but productive farmers representing more than $80 \%$ of farm population are usually unable to purchase required quantities of the inputs for application for better yield. Therefore, these farmers need to be supported by adequate and timely supply of credit to narrow yield gaps. But the current credit system in Bangladesh remains far below the needs of small farmers. They have very limited access to institutional credit mainly because of collateral requirement. Therefore, appropriate measures must be taken to reduce transaction costs, simplify lending procedures, revise eligibility criteria and strengthen monitoring and supervision mechanism of the credit system. The action may also be taken for the expansion of rural bank branches under public sector. 


\section{Research and extension support}

The support of research and extension is necessary for narrowing yield gap. The researcher should understand farmers' constraints to high productivity and accordingly develop integrated technological package (appropriate variety, timely planting, fertilizer, irrigation, and pest management) for farmers for specific locations to bridge up the gaps. The extension service should at the same time ensure that the farmers apply correctly and systematically the recommended technological packages in fields through effective training, demonstrations, field visits, monitoring, etc. The judicious application of inputs from seeding to heading in terms of quantity and timing will significantly contribute to reducing yield gaps and thereby increasing productivity of crops.

\section{Policy support}

As mentioned earlier, socio-economic and institutional/policy constraints can cause yield gap significantly. It is thus necessary that the government address the issues seriously and come forward with solutions to the problems to increase productivity by minimizing the yield gaps. Hanson et al. (1982) recommended that the government find solutions to socio-economic and political questions for narrowing the agronomic gap between farmers' fields and the research stations.

\section{Conclusions}

In many countries of the world, yield gaps in crops between potential and farmers' yields are still substantially high due to the combination of constraints, such as poor management and economic conditions of farmers and lack of resources, especially credit and knowledge and commitment of the government. Efforts should, therefore, be made to minimize the yield gaps and increase and sustain production and productivity of crops by properly addressing the constraints. It is also essential to promote collaboration among research, extension, NGOs, and private sector to develop appropriate technologies with a view to narrowing yield gaps.

\section{Recommendations}

- The government must strengthen efforts to ensure timely supply of adequate quantities of quality inputs to the farmers to enable them to minimize yield gap in crops. Both public and private sectors should play a vital role in producing and distributing the inputs in time.

- Efforts must be made to update/enrich farmers' knowledge and skill on the causes of yield gaps and the strategies to minimize the gaps through training, demonstrations, field visits, and monitoring by extension agencies. 
- Despite the training and skill provided to them, resource-poor small farmers may not be able to achieve high yield. This is because these farmers are not usually able to purchase required quantities of the inputs to obtain such yield. It is, therefore, essential for the government to take steps to timely supply adequate amounts of credit to these farmers. Actions should also be taken to reduce transaction costs, simplify lending procedures, revise eligibility criteria and strengthen monitoring and supervising mechanism of the current credit system.

- Alternatively, a new institution/foundation following the model of Palli Karmo Sahayak Foundation (PKSF) should be established along with necessary manpower and other facilities to cater to the needs of resourcepoor small farmers.

- Socio-economic and institutional constraints, such as poor economic status of farmers, lack of supply of quality inputs, input/output price support and proper research-extension linkage can cause yield gaps in crops. It is recommended that the government address the issues seriously and come forward with appropriate solutions to the problem of yield gap.

- Support of research and extension is necessary for narrowing yield gap. The researcher should understand farmers' constraints to high productivity and accordingly develop integrated technological package (appropriate variety, timely planting, fertilizer, irrigation, and pest management) for specific locations to bridge up the gap. The extension service should at the same time ensure that the farmers properly apply recommended technological packages in fields through effective training, demonstrations, field visits, monitoring, etc.

- Efforts of the government are at present mainly confined to the use of modern varieties and hybrid technology to increase crop production. The government should realize the fact that yield gaps exist in different crops of Bangladesh. It is, therefore, recommended that they seriously explore the scope to promote yield by narrowing the existing yield gaps in crops and thereby ensure food security

\section{References}

Annual Report, OFRD, BARI. 2008-2009. Yield gap analysis of mustard in the farmers' fields.

Annual Report, OFRD, BARI. 2003-2004. Yield gap analysis of wheat under different management situation at MLT site, Palashbari, Rangpur.

Annual Report, OFRD, BARI. 2003-2004.Yield gap analysis of chickpea under different management situation at Nachole, Chapainawabgonj. 
Aggarwal, P. K., KB Hebbar, M. V. Venugopalan, S. Rani, A. Bala, A. Biswal and S. P. Wani. 2008. Quantification of yield gaps in rainfed rice, wheat, cotton and mustard in India. ICRISAT. Global theme on Agro-ecosystems report \# 43.

Alam, M. 2006. Factors affecting yield gap and efficiency in rice productions in some selected areas of Bangladesh. A thesis submitted for the degree of Ph.D. Dept. of Economics, Jahangir Nagar University, Bangladesh.

BRRI. 2011. Study findings presented in a workshop held in May 2011 on "minimizing rice yield gap” at BRRI, Gazipur

De Datta, SK.1981. Principles and Practices of Rice Production.New York (USA):Wiley Inter Science Publications. 618p.

Hanson H., E. Borlaug, R. G. Anderson. 1982. Narrowing the yield gap: Wheat in the Third World.Boulder, Colorado (USA), West View Press. p. 127-133.

Matin, M. A, A. S. M. Anwarul Huq, M. S. Hussain, Md. Ruhul Karim and Elahi Baksh. 1996.Farm level yield analysis of tomato cultivation in selected areas of Bangladesh: An economic profile. Bangladesh J. Agric. Res. 21 (1).

National Food Policy _Plan of Action (2008-2015).2008. Food Planning and Monitoring Unit, Ministry of Food and Disaster Management, Govt. of Bangladesh.

Roy, Indrajit.1997. Stagnating productivity in crop agriculture. The quest for sources of growth. Environment and agricultural productivity in Bangladesh. Bangladesh Academy of Agriculture (BAAG).

RAP (Regional Office for Asia and the Pacific). 1999. Report of the expert consultation on bridging rice yield gap in the Asia- Pacific region. FAO.

Siddiq, E. A. 2000. Bridging rice yield gap in India. In: Proceedings of Expert Conference on bridging the rice yield gap in the Asia- Pacific region, RAP, FAO.

Status of oil crop production in Bangladesh, 2002. ORC, BARI.

Tran, Dat Van. 2000. Closing the rice yield gap for food security. International Rice Commission, FAO. 